\title{
PRESENCE OF hemA-LIKE AND hemT-LIKE GENES IN A JSUMBER OF ANOXYGENIC PHOTOSYNTHETIC BACTERIAL ISOLATES FROM INDONESIA AND SOIL SAMPLES FROM BOGOR AREA
}

\author{
NURUL AINI'AND ANTONIUSSUWANTO' ${ }^{2}$ - \\ 'Laboratory of Microbiology and Biochemistry, Inter University Centre for Biotechnology, \\ Bogor Agricultural University, Bogor-16680 Indonesia. \\ Department of Biology, Faculty of Science and Mathematics, Bogor Agricultural University, \\ Bogor 16144, Indonesia. \\ 'South-East Asian Regional Center for Tropical Biology, Bogor-16001, Indonesia.
}

\begin{abstract}
The Rhodobacter sphaeroides hemA and hem $T$ are known to encode a distinct 5-aminolevulinic acid (ALA)-synthase isozyme. This enzyme catalyzes the first and rate limiting step in ALA biosynthesis through the $\mathrm{C}_{4}$ pathway. This study was carried out to detect hemA-I|ke and hemT-I|ke genes in twenty Anoxygenic Photosynthetic Bacterial (APB) isolates from several wetland areas in Indonesia, and four DNA samples that were isolated from four soil samples obtained from Bogor area. Hybridization techniques of Southern and dot blot were used, using hemA and hemT fragment as probes. Southern hybridization analyses indicated the presence of hemA-l|ke gene in five of APB isolates, i.e., MB15, MB16, MB21.2, MB55 and MB6, whereas hemT-Ilke gene was detected only in MB15. Dot blot hybridization analyses suggested that the soil samples from waterlogged paddy-field, dry paddy-field as well as a mud pond were predominantly occupied by prokaryotic organisms which harboured hemA-] lke gene. However, /iem7"-like sequences were also found in soil sample from dry paddy-field.
\end{abstract}

Key words: hemA-||ks gene / hemT-||ke gene / Southern hybridization analysis / dot blot hybridization analysis.

\section{INTRODUCTION}

The Rhodobacter sphaeroides hemA and hemT genes encode a distinct 5aminolevulinic acid (ALA) synthase isozyme (Neidle \& Kaplan 1993). ALAsynthase catalyzes the first and rate-limiting step in ALA biosynthesis through the $\mathrm{C}_{4}$ pathway. ALA is the first committed precursor in the common tetrapyrrole pathway (Goodwin \& Mercer 1986; Beale \& Weinstein 1991; Beale 1995). Recently, ALA has received attention as a new biodegradable herbicide (Sasaki et al. 1987) and insecticide (Sasaki et al. 1990).

The DNA sequences of hemA and hemT genes and their location on $R$. sphaeroides physical map have been determined. The hemA gene is located on the large chromosome whereas hemT gene is found on the small chromosome (Neidle \& Kaplan 1993a). The hemA and hemT genes encode peptides that are 53\% similar to each other, and these peptides are also significantly similar to ALA-synthase from several bacteria and eucaryotic species (Neidle \& Kaplan 1993). The hemA fragment has been cloned in $R$. sphaeroides (Tai et al. 1988) as well as in Escherichia 
coli (Werf \& Zeikus 1996). The cloned hemA fragment is expressed well in E. coli and able to enhance ALA production (Werf \& Zeikus 1996). This evidence shows that hemA can be used as a genetic material for enhancing ALA production.

Since hemA and hemT genes have high homology to gene encoding ALAsynthase from other organisms, hemA-Vlke and hemT-Vlke genes might be found in other bacteria that form ALA through the $\mathrm{C}_{4}$ pathway. In this study, we detected the presence of hemA-Ilke and hemT-like genes in Anoxygenic Photosynthetic Bacterial (APB) isolates, because most member of APB use the $C_{4}$ pathway to produce ALA. Soil, especially paddy-field soil, is known as a common habitat of APB (Habte \& Alexander 1980: Gest et al. 1985). Therefore, we also carried out an experiment to detect these genes in four soil samples. The results of this study would be expected to generate some insights on the distribution and population density of APB as well as $R$, sphaeroides strains. In addition, the specificity of hem $T$ would be assessed to be used as a specific molecular marker for $R$. sphaeroides isolates.

\section{MATERIALS AND METHODS}

\section{Bacterial strains, plasmids, growth conditions and soil samples}

The bacterial strains and plasmids used are listed in Table 1. APB isolates were grown photoheterotrophically in Sistrom's minimal medium (Lueking et al. 1978) in full filled screw-cap tubes, $\mathrm{pH}$ 7.2. E. coli were grown at $37^{\circ} \mathrm{C}$ in Luria Bertani (LB)

Table 1. Bacterial strains and plasmids

\begin{tabular}{|c|c|c|}
\hline $\begin{array}{l}\text { Bacteria and strains or } \\
\text { plasmids }\end{array}$ & Relevant characteristics & Reference \\
\hline $\begin{array}{l}\text { APB isolates: } \\
\text { MB2 } \\
\text { MB6 } \\
\text { MB7 } \\
\text { MB11.1 } \\
\text { MB12.2 } \\
\text { MB15 } \\
\text { MB16 } \\
\text { MB18 } \\
\text { MB19 } \\
\text { MB21.1 } \\
\text { MB21.2 } \\
\text { MB22 } \\
\text { MB23 } \\
\text { MB28 } \\
\text { MB31 } \\
\text { MB39 } \\
\text { MB54 } \\
\text { MB55 }\end{array}$ & $\begin{array}{l}\text { Wild type, from Central Kalimantan } \\
\text { Wild type, from Central Kalimantan } \\
\text { Wild type, from Central Kalimantan } \\
\text { Wild type, from Central Kalimantan } \\
\text { Wild type, from Central Kalimantan } \\
\text { Wild type, from Bogor } \\
\text { Wild type, from Pangandaran } \\
\text { Wild type, from Ciwaluya } \\
\text { Wild type, from Bogor } \\
\text { Wild type, from Ciamis } \\
\text { Wild type, from Ciamis } \\
\text { Wild type, from Pontianak } \\
\text { Wild type, from Ujung Kulon } \\
\text { Wild type, from Ujung Kulon } \\
\text { Wild type, from Ujung Kulon } \\
\text { Wild type, from Merauke } \\
\text { Wild type, from Jambi } \\
\text { Wild type, from Iambi }\end{array}$ & $\begin{array}{l}\text { Irawan et al. }(1998) \\
\text { Irawan et al. (1998) } \\
\text { Irawan et al. (1998) } \\
\text { Irawan et al. }(1998) \\
\text { Irawan et al. }(1998) \\
\text { Irawan et al. }(1998) \\
\text { Irawan et al. }(1998) \\
\text { Irawan et al. }(1998) \\
\text { Irawan et al. }(1998) \\
\text { Irawan et al. }(1998) \\
\text { Irawan et al. }(1998) \\
\text { Irawan et al. (1998) } \\
\text { Irawan et al. }(1998) \\
\text { Irawan et al. }(1998) \\
\text { Irawan et al. }(1998) \\
\text { Irawan et al. }(1998) \\
\text { Irawan et al. (1998) } \\
\text { Irawan et al. }(1998)\end{array}$ \\
\hline
\end{tabular}


Table 1. Continued

\begin{tabular}{|c|c|c|}
\hline $\begin{array}{l}\text { Bacteria and strains or } \\
\text { plasmids }\end{array}$ & Relevant characteristics & Reference \\
\hline $\begin{array}{l}\mathrm{MCl} \\
\mathrm{BW} 12\end{array}$ & $\begin{array}{l}\text { Wild type, from Kotorayo } \\
\text { Wild type, from Central Kalimantan }\end{array}$ & $\begin{array}{l}\text { Irawan et al. (1998) } \\
\text { Irawan et al. (1998) }\end{array}$ \\
\hline $\begin{array}{l}R . \text { spaeroides } 2.4 .1 \\
S . E . \text { coli }\end{array}$ & $\begin{array}{l}\text { Wild type, from USA } \\
\text { supE44 AlacU169 }\end{array}$ & $\begin{array}{l}\text { Suwanto \& Kaplan (1989) } \\
\text { Sambrook et al., } 1989\end{array}$ \\
\hline $\begin{array}{l}\text { Plasmids: } \\
\text { pUC19 } \\
\text { pUI 1004 } \\
\text { pUI1014 } \\
\text { pUI612 } \\
\text { pHF1.1 }\end{array}$ & $\begin{array}{l}\text { Ampr } p^{r} \text {, acI, lac } Z \\
\text { pUC18, } 1.8 \mathrm{~kb} \text { hemT } \\
\text { pUC18, } 2 \mathrm{~kb} \text { hemA } \\
\text { pUC18, } 1.08 \mathrm{~kb} \text { pucBA } \\
\text { pHE3, } 2.2 \mathrm{~kb} \text { I6S \& } 23 \mathrm{~S} \text { rrna }\end{array}$ & $\begin{array}{l}\text { Sambrook et al., 1989 } \\
\text { Neidle \& Kaplan, 1993a } \\
\text { Neidle \& Kaplan, 1993a } \\
\text { Kiley \& Kaplan, 1987 } \\
\text { Schleifer et al., } 1985\end{array}$ \\
\hline
\end{tabular}

(Sambrook et al. 1989) supplemented as needed with antibiotics. Antibiotics were added at the following concentrations: 100|ag Ampicillin/ml (for maintaining pUC19, pUI1004, pUI1014, and pUI612), 25|ig Chloramphenicol/ml (for maintaining pHFl.l). Soil samples were taken from waterlogged paddy-field, dry paddy-field, LSI pond and Grawida yard, Bogor Agricultural University, Darmaga Campus. All sampling areas were located at Darmaga, Bogor. The description of the soil samples are listed in Table 2.

Table 2. Soil samples

\begin{tabular}{|c|l|l|}
\hline No. & Sampling Location & \multicolumn{1}{c|}{ Soil Description } \\
\hline 1. & Waterlogged paddy field & Dark brown, wateriogged, sandy, $\mathrm{t}: 27^{\circ} \mathrm{C}$ \\
2. & Dry paddy field & Dark brown, dry, finely granulated, porous, $\mathrm{t}: 29^{\circ} \mathrm{C}$ \\
3. & LSI pond & Dark brown, silt, $\mathrm{t}: 26^{\circ} \mathrm{C}$ \\
4. & Grawida Yard & Red brick, massive, clayey, $\mathrm{t}: 29^{\circ} \mathrm{C}$ \\
\hline
\end{tabular}

\section{DNA isolation}

Plasmids DNA were isolated by using Wizard Miniprep DNA Purification System (Promega, Wise.) according to the manufacturer's instruction. Genomic DNA was extracted from each APB isolate using the phenol extraction method with slight modification as follows. The cell pellet was suspended in EDTA solution containing $15 \mathrm{mg}$ lysozyme $/ \mathrm{ml}$, and incubated at $37^{\circ} \mathrm{C}$ for 1 hour. The lysis was accomplished by adding $300 \mathrm{ul}$ SDS buffer $(0.1 \mathrm{M} \mathrm{NaCl}$; $\%$ SDS; $0.5 \mathrm{M}$ Tris-HCl, $\mathrm{pH}$ 8). The extract was freeze-thawed. The DNA was phenol-extracted and ethanol- 
precipitated as in standard protocol (Sambrook et al. 1989). The E. coli genomic DNA was isolated as described previously (Leach et al. 1994).

The DNA was extracted from soil by using modified Tiedje Method (Keller 1997, unpublished). The soil sample (10 g) was finely grinded. The $5 \mathrm{~g}$ grinded soil was mixed with $13.5 \mathrm{ml}$ Tiedje buffer (100 mM Tris-HCl, pH 8; $100 \mathrm{mM}$ NaEDTA, pH 8; 100 mM Na $2 P_{4}$, pH 8; $1.5 \mathrm{M} \mathrm{NaCl}$; 1\% CTAB) in $100 \mathrm{ml}$ centrifuge tube, and freeze-thawed 3x. After freeze-thawing, $100 \mathrm{ul}$ proteinase-K $(20 \mathrm{mg} / \mathrm{ml})$ (Sigma, Singapore) was added and incubated at $37^{\circ} \mathrm{C}$ for 30 minutes, then $10 \mathrm{ml}$ $10 \%$ SDS was added and incubated at $65^{\circ} \mathrm{C}$ for 2 hours. The mixture was centrifuged at $6000 \mathrm{~g}$ for 10 minutes. The supernatant was extracted with 1 volume of chloroform (Merck, Jakarta) and centrifuged at $6000 \mathrm{~g}$ for 1 minute. The aqueous phase was transferred to a new $100 \mathrm{ml}$ centrifuge tube and 0.6 volume of isopropanol (Merck, Jakarta) was added at room temperature. The DNA was recovered by centrifugation at $16,000 \mathrm{~g}$ for 20 minutes at $4^{\circ} \mathrm{C}$. The supernatant was discarded and the pellet was washed with $70 \%$ ethanol. The DNA was dried at room temperature and dissolved in 100 ul TE buffer (OmM Tris-HCl, pH 8; Im M EDTA).

\section{Southern hybridization analysis}

The $1.2 \mathrm{~kb}$ Bamttl (NEB, Singapore) fragment from pUI1014 and $1.8 \mathrm{~kb}$ Bam III (NEB, Singapore) fragment from pUI1004 were isolated for preparing hemA and hem $T$ probes. The fragments were purified from agarose gel using the Gene Clean Kit (Bio 101 Inc, La Jolla, Calif.), and labeled with biotin-14-ATP using Nick Translation System (GIBCO/BRL, Grand Island, NY) according to the manufacturer's instruction. The unincorporated nucleotides were removed from the probes with nuctrap push columns (Stratagene, La Jolla, Calif.).

The genomic DNAs extracted from APB isolates were digested with EcoRl (NEB, Singapore), except the DNA from MB 15 isolate, which was digested with Bam III (NEB, Singapore). Digestions were performed in appropriate buffer at $37^{\circ} \mathrm{C}$ for 12 hours. The digested DNA was electrophoretically separated. The DNA fragments were transferred to a nylon membrane (Photogene, GIBCO/BRL, Grand Island, NY) by capillary action with standard method (Sambrook et al. 1989). Hybridization was carried out as described previously at $42^{\circ} \mathrm{C}$ for 12 hours (Sambrook et al. 1989), followed by washing at $37^{\circ} \mathrm{C}$ for $2 \mathrm{x} 15$ minutes each, and detection using a chemiluminescent method (Photogene Detection System, GIBCO/ BRL, Grand Island, NY).

\section{Dot blot hybridization analysis}

Four biotinilated DNA probes, i.e. hemA, hemT, pucBA, and I6S rRNA genes were used. The probes were prepared as described above. To avoid bias in calculation, the population density of prokaryotes was based on the same amount of soil samples, and not on the same amount or standardization of DNA concentration. DNA isolated from soil samples were denatured as described previously (Keller and 
Manak 1992), and applied to nylon membrane (Photogene, GIBCO/BRL, Grand Island, NY) by spotting directly onto the membrane. High stringency hybridization and washing conditions were used. Hybridization was carried out at $42^{\circ} \mathrm{C}$ for 12 hours, with washing temperature of $55^{\circ} \mathrm{C}$ (Sambrook et al. 1989). Detection was done using the Photogene Detection System (GIBCO/BRL, Grand Island, NY).

\section{RESULTS AND DISCUSSION}

Southern hybridization analyses

Southern hybridization analyses were performed to determine the presence of hemA-like and hemT-Ilke genes in twenty APB isolates from Indonesia (Table 1). $R$. sphaeroides 2.4.1 (Rsp 2.4.1) hemA and hemT genes were used as probe. The analyses identified some homologous regions the homology to hemA in the genomic DNA of MB6, MB 15, MB 16, MB21.2 and MBS 5. The region of homology to hemA probe in the genomic DNA of each APB isolate is shown in Figure la, lanes 3-7. The hemTprobe hybridized only to $4.8 \mathrm{~kb} \mathrm{BamHl}$ fragment in MB15 genomic DNA (Fig. Ib, lane 3).

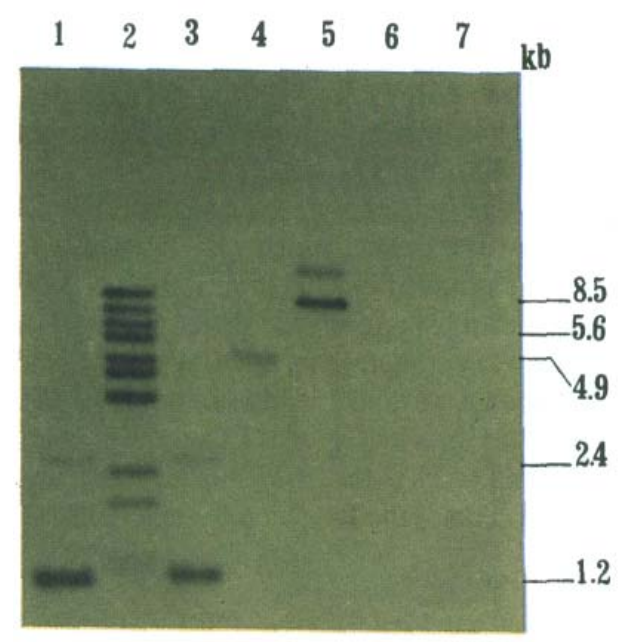

A

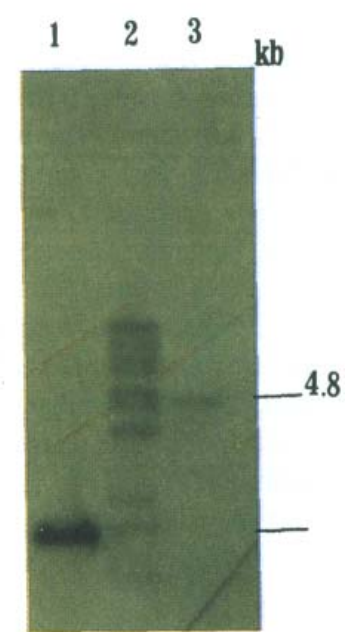

B

Figure 1. A. Southern hybridization analyses using hemA probe. Lanes (1) Rhodobacter sphaeroides 2.4.1, (2) KBslEll, (3) MB15, (4)MB16, (5) MB21.2, (6) MB55, and (7) MB6

B. Southern Hybridization analyses using hemTprobe Lanes (1) Rhodobacter sphaeroides 2.4.1, (2) KBslEll, and (3) MB 15 
The results implied the presence of hetnA-like gene in MB6, MB15, MB16, MB21.2 and MB55, whereas hemT-like gene was only implied in MB 15. The presence of hemA-like and/or hemT-like genes in the five APB isolates indicates the ALA biosynthesis in these APB isolates is employed through the $\mathrm{C}_{4}$ pathway, because the $\mathrm{C}_{4}$ pathway is mediated by ALA synthase which encoded by hemA and/or hemTgenes. Moreover, the presence of hemA-like and/or hemT-like genes in the five APB isolates indicates that these APB isolates could be classified under sub group cc-proteobacteria. In photosynthetic bacteria, $\mathrm{C}_{4}$ pathway is utilized by purple non-sulfur bacteria, especially sub group a-proteobacteria (Avissar et al. 1989; Beale 1995). The sub group a-proteobacteria contains species of genera Rhodospirillum, Rhodopila, Rhodopseudomonas, Rhodomicrobium and Rhodobacter (Imhoff 1995).

Neither hemA-like gene nor hemT-like gene was identified in the other 15 APB isolates. The data suggested that the $\mathrm{C}_{4}$ pathway is not utilized by these APB isolates to produce ALA. The 15 APB isolates might produce ALA through $\mathrm{C}_{5}$ pathway, which does not require ALA synthase. These APB isolates used are not the member of sub group a-proteobacteria, although all APB isolates studied here belong to purple non-sulfur bacteria.

The hemT-like gene was only identified in MB 15. This APB isolate also carries hemA-like gene. Interestingly, the hemA-like gene in MB 15 was detected on the same locations with Rsp. 2.4.1 hemA, i.e., at $1.2 \mathrm{~kb}$ and $2.4 \mathrm{~kb} \mathrm{BamHl}$ fragments (Fig. la, lane 1 and 3 ). The strong intensity of the hybridization signals revealed that the similarity between MB 15 hemA-like gene and Rsp.2.4.1 hemA was very high. Moreover, the color comparison of MB 15 culture with Rsp. 2.4.1 culture also showed a high similarity. Based on these findings, it is very likely that MB 15 was Rhodobacter sphaeroides. We tentatively conclude that hemT-like gene harbors specifically in $R$. sphaeroides. Neidle and Kaplan (1993) reported that the $R$. sphaeroides is the only bacterial species that produces two ALA synthase isozymes. However, previously ALA synthase isozymes are found in some vertebrates (Dierks 1990), while no previous information on bacterial ALA synthase isozymes have been reported.

Dot blot hybridization analysis

Dot blot hybridization analysis was employed to detect the presence of hemAlike and hemT-like genes in DNA extracted from four soil samples (Table 2). Four DNA probes, i.e., hemA, hemT, pucBA, and 16S rRNA gene were used. This analysis also revealed the relationship of the activity of prokaryote and APB in the soil samples with the presence of hemA-like and hemT-like genes.

Figure 2 shows the results of dot blot hybridization using the four probes. Interpretation of these results is described in Table 3. Based on the hybridization using hemA probe (Fig. 2a), the presence of hemA-like gene was detected in soils taken from waterlogged paddy field, dry paddy field and LSI pond. The presence of hemA-like gene in these soil samples indicates the activity of organisms producing 
ALA through the $\mathrm{C}_{4}$ pathway. The $\mathrm{C}_{4}$ pathway is utilized by animals, fungi, protozoa and sub group cc-proteobacteria (Avissar et al. 1989; Beale \& Weinstein 1991; Beale 1995).

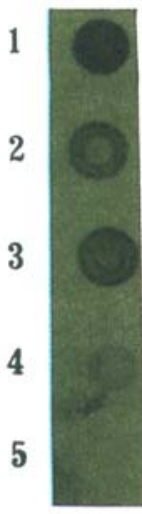

A

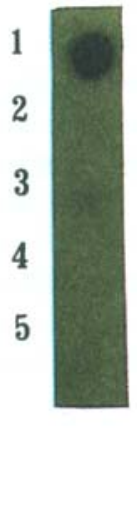

B

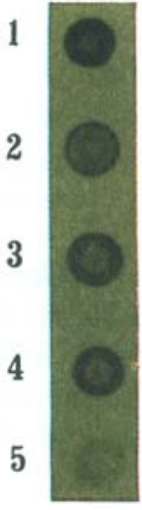

C
1

2

3

4

5

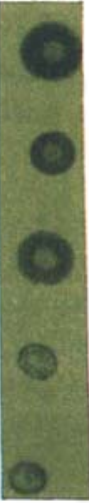

D

Figure 2. Dot blot hybridization analyses using $\operatorname{HemA}(\mathrm{A})$, hemT(B), 16S rRNA (C), and pucBA (D) as probes. Dots (1) Rhodobacter sphaeroides 2.4.1., (2) soil sample from, waterlogged paddy field, (2) soil sample from dry paddy field, (3) soil sample from LSI pond, and (5) soil sample from Grawida yard

Table 3. Interpretation of the result of dot blot hybridization

\begin{tabular}{|c|l|c|c|c|c|}
\hline \multirow{2}{*}{ No. } & \multicolumn{2}{|c|}{ Soil Samples } & \multicolumn{3}{|c|}{ Interpretation of Dot Blot Hybridization Results } \\
\cline { 3 - 6 } & & $h e m A$ & $h e m T$ & Prokaryote & APB \\
\hline 1 & Waterlogged paddy field & ++ & - & ++ & ++ \\
2 & Dry paddy field & +++ & ++ & ++++ & +++ \\
3 & LSI pond & + & - & +++ & + \\
4 & Grawida Yard & - & - & + & + \\
\hline
\end{tabular}

- : Nodetected

The number of $(+)$ represent the degree of intensity of hybridization signal 
Using 16S rRNA probe, we identified the presence of prokaryotic microorganisms in all four soil samples (Fig. 2c). The results of hybridization to pucBA probe indicated that the APB could be detected in all soil samples (Fig. 2d). Thus, it is possible to find the ct-proteobacteria in the soil samples, because some members of oc-proteobacteria are classified as APB group. The possibility for the ct-proteobacteria to exist in the four soil samples correlates with the presence of hemA-llke gene in these soil samples. However, in spite of the detection of the APB activities in soil from Grawida yard, hemA-like gene was not found in this soil. The intensity of hybridization signal to both 16S rRNA (Fig. 2c) and pucBA (Fig. 2d) probes shows that the population densities of both prokaryote and APB in soil from Grawida yard are much lower than those found in the other three soil samples. The a-proteobacteria might not exist in the soil from Grawida yard or the ccproteobacteria were actually present in this soil, but the population density is very low. Therefore, presence of hemA-Yike gene could not be detected. Soils obtained from waterlogged paddy field, dry paddy field and LSI pond were found to have high population density of prokaryotes and APB. The high population density of APB enables the a-proteobacteria to proliferate. The presence of hemA-Vlke gene in these soil samples is related to the population density of APB. The population density of APB as well as other microorganisms in the soil is dependent on the availability of growth nutrient, $\mathrm{O}_{2}$ and water (Brock \& Madigan, 1991). The fertility and the soil texture are responsible for the availability of these factors. Therefore, the presence of HemA-like gene in soil is indirectly affected by the fertility and the soil texture

Based on the results of hybridization to hemA probe, the hemA-like gene might be present in the soil taken from APB habitat. In nature, APB occur in moist soil, paddy field, sewage water, fresh water, brackish water, waste water, marine habitat and in extreme condition of the Antartic (Sasikala et al. 1985). The presence of hemA-like gene in the soil is related to the fertility of the soil, because the availability of growth nutrient affects APB growth.

The dot blot hybridization using hemT probe identified the presence of hemTlike gene only in soil taken from dry paddy field (Fig. 2b, dot 3). By comparing the intensity of hybridization signal to hem $T$ probe with the hybridization signal to hem $A$ probe, it is clear that the homologous sequence to hem $T$ probe is present in relatively fewer amount than the homologous sequence to hemA probe. The results indicate that not all organisms carrying hemA-Ilke gene also carry the hemT-like gene. These findings confirm the data obtained from Southern hybridization analyses that the presence of hemT-like gene is more specific than that of hemA-like gene. The hemT or hemT-Ilke gene might be specific to $R$. sphaeroides. However, further studies to determine the nature of specificity of hemT or hemT-Ilke gene to $R$. sphaeroides should be carried out to develop in situ hybridization method to examine directly the distribution and density of $R$. sphaeroides in the soil or water ecosystem. 


\title{
ACKOWLEDGMENTS
}

\author{
This research was supported by a Competitive Grant (Hibah Bersaing V, grant \\ 08/P21 PT/DPPM/96/PHBV/I/V/1996) to Antonius Suwanto.
}

\section{REFERENCES}

Avissar, Y.J., J. Ormerod, and S.I. Beale. 1989. Distribution of 6-aminolevulinic acid biosynthetic pathway among photosynthetic bacteria and related organism. Arc. Microbiol. 151:513-519.

Beale, S.I. 1995. Biosynthesis and structure of porphyrine and hemes. In: R.E. Blakenship, M.T. Madigan, and C.E. Bauer (eds). Anoxygenic Photosynthetic Bacteria. Kluwer Academic Publisher. Netherlands, p. 847-870.

Beale, S.I., and J.D. Weinstein. 1991. Biosynthesis of of 8-aminolevulinic acid in phototropic organism. In. H. Scheer (ed). Chlorophylls. CRC Press. Boca Raton. p. 368-392.

Brock, T.D., and M.T. Madigan. 1991. Biology of Microorganism. Prentice-Hall International Inc. USA. p. 566-569, 703-726.

Dierks, P. 1990. Molecular biology of eukaryot 5-aminolevulinate synthase. In H.A. Dailey (ed). Biosynthesis of hemes and chlorophylls. McGraw-Hill. New York. p. 210-234.

Gest, H., J.L. Favinger, and M.T. Madigan. 1985. Exploitation of $\mathrm{N}_{2}$ fixation capacity for enrichment of anoxigenic photosyntetic bacteria in ecological studies. FEMS Microbiol. Ecol. 31: 317-322.

Goodwin, T.W., and E.I. Mercer. 1986. Introduction to Plant Biochemistry. Pergamon Press. Oxford, p. 465-467.

Habte, M., and M. Alexander. 1980. Nitrogen fixation by photosynthetic in lowland rice culture. Appl. Environ. Microbiol. 39: 342-347.

Imhoff, J.F. 1995. Taxonomy and physiology of photosynthetic purple bacteria and green sulfur bacteria. In: R.E. Blakenship, M.T. Madigan, and C.E. Bauer (eds). Anoxygenic Photosynthetic Bacteria. Kluwer Academic Publisher. Netherland. p. 1-15.

Irawan, A. Suwanto, P.D. Tjondronegoro. 1998. Isolation and screening of anoxygenic photosynthetic bacteria producing extracellular L-aminolevulinat acid. Hayati. 5: 98-102.

Keller, G.H., and M.M. Manak. 1992. DNA Probes. Stockton Press. UK. p. 1-16.

Kiley, J. P, and S. Kaplan. 1987. Cloning DNA sequence and expression of the Rhodobacter sphaeroides light-harvesting 8800-850-a and B800-850-P genes. J. Bacteriol. 169: 3268-3275.

Leach, J. E., F.F. White, M.L. Rhoads, and H. Leung. 1994. A repetitive DNA sequence differentiates $X$. campestris p.v. oryzae from other patovar of $X$. campestris. Mol. Plant-Microb. Interact. 98: 238246.

Leuking, D.R., R.T. Faley, and S. Kaplan. 1978. Intracytoplasmic membrane synthesis in synchronous cell population of Rhodopseudomonas sphaeroides. J. Biol. Chem. 253: 451-457.

Neidle, E.L., and S. Kaplan. 1993. Expression of the Rhodobacter sphaeroides hemA and hemT genes, encoding two 5-aminolevulinic acid synthase isozymes. J. Bacteriol. 175: 2292-2303.

Sambrook, J.E., F. Fritsch, and T. Maniatis. (1989). Molecular Cloning. Cold Spring Harbor Laboratory Press. USA. p. 9.31-9.58. 
BIOTROPIA NO. 15, 2000

Sasaki, K., S. Ikeda, Y. Nishizawa, and M. Hayashi. 1987. Production of 5-aminolevulinic acid by photosynthetic bacteria. J. Ferment. Technol. 65: 511-515.

Sasaki, K., N. Noparatnaraporn, S. Nagai. 1990. Production of 5-aminolevulinic acid as a herbicide from swine waste by Rhodobacter sphaeroides. Ann. Rep. 1C Biotech. 13: 277-281.

Sasikala, K., Ch. V. Ramana, P.R. Raghureer. and K.L. Kovacs. 1985. Anoxygenic photosynthetic bacteria: physiology and advances in hydrogen production technology. Adv. App. Microbiol. 28: 211-295.

Schleifer, K.H., W. Ludwig, J. Krauss, and H. Festl. 1985. Cloned ribosomal RNA genes from Pseudomonas aeruginosa as probe for conserved deoxyribonucleic acid sequences. Int. J. Syst. Bact. 38:231-237.

Suwanto, A., and S. Kaplan. 1989. Physical and genetic mapping of the Rhodobacter sphaeroides 2.4.1 genome: presence of two unique circular chromosomes. J. Bacteriol. 171: 5850-5859.

Tai, T.N., M.D. Moore, and S. Kaplan. 1988. Cloning and Characterization of the 5-aminolevulinic synthase gene(s) from Rhodobacter sphaeroides. Gene. 70: 139-151.

Werf, M. J., and J. G. Zeikus. 1996. 5-Aminolevulinat production by Escherichia coli containing the Rhodobacter sphaeroides hemA gene. Appl. Environ. Microbiol. 62: 3560-3566. 